\title{
Tingkat Ketercapaian Tugas Perkembangan Dewasa Awal: Studi Deskriptif pada Mahasiswa IAIN Curup
}

\author{
Dewi Purnama Sari \\ Institut Agama Islam Negeri (IAIN) Curup \\ dewipurnamasari@iaincurup.ac.id
}

\begin{abstract}
The purpose of this study is to see the level of achievement of student development tasks to be used as a basic reference in providing guidance, assistance and designing activity programs to develop student potential. This research is a quantitative descriptive study that aims to obtain information on the level of achievement of student development tasks at the Tarbiyah Faculty of IAIN Curup. This study involved 30 PAI study program students, 30 PGMI students, 25 BKPI students, 25 English students and 16 PBA students. Data on the level of achievement of student development was collected using the Student Development Task Inventory (ITPPT) and then analyzed by statistical analysis of percentages. As a result, the average level of achievement of student development tasks is at the individuality level. There are four aspects of development that have reached the stage of autonomy, namely awareness of responsibility achieved by students of the Islamic Religious Education (PAI) study program and students of the Guidance and Counseling (BK) study program. The basic aspects of life achieved by students of the English Language Education (PBI) study program and aspects of self-acceptance and development have also reached the level of autonomy. Following up on the findings of this study, mastery of the level of achievement of student developmental tasks can be optimized through guidance and counseling activities.
\end{abstract}

Keywords: Level of achievement; developmental tasks; early adulthood

\begin{abstract}
Abstrak
Tujuan penelitian ini untuk melihat tingkat ketercapaian tugas perkembangan mahasiswa guna dijadikan acuan dasar dalam memberikan bimbingan, bantuan dan merancang program kegiatan
\end{abstract}


untuk mengembangkan potensi mahasiswa. Penelitian ini merupakan studi deskriptif kuantitatif yang bertujuan untuk mendapatkan informasi tingkat ketercapaian tugas perkembangan mahasiswa Fakultas Tarbiyah IAIN Curup. Kajian ini melibatkan126 mahasiswa program studi PAI 30 orang, PGMI 30 orang, BKPI 25 orang, Tadris Bahasa Inggris 25 orang dan PBA 16 orang. Data tingkat ketercapaian tugas pekembangan mahasiswa dikumpulkan dengan Inventori Tugas Perkembangan Mahasiswa (ITP-PT) kemudian dianalisis dengan analisis statistik persentase. Hasilnya, rata-rata tingkat ketercapaian tugas perkembangan mahasiswa berada pada tingkat individualitas. Ada empat aspek perkembangan yang sudah mencapai tahap otonomi, yaitu kesadaran tanggung jawab dicapai oleh mahasiswa program studi Pendidikan Agama Islam (PAI) dan mahasiswa program studi Bimbingan dan Konseling (BK) . Aspek landasan hidup relegius dicapai oleh mahasiswa program studi Pendidikan Bahasa Inggris (PBI) dan untuk aspek penerimaan diri dan pengembangannya juga sudah mencapai tingkat otonomi. Menindaklanjuti temuan penelitian ini, penguasaan tingkat ketercapaian tugas perkembangan mahasiswa dapat dioptimalkan melalui kegiatan bimbingan dan konseling.

Kata Kunci: Tingkat ketercapaian; tugas perkembangan; dewasa awal

\section{Pendahuluan}

Tugas perkembangan merupakan serangkaian sikap, perilaku atau keterampilan yang mesti dikuasai oleh setiap individu dalam setiap fase perkembangan tertentu. ${ }^{1}$ Tugas perkembangan muncul sebagai akibat dari adanya kematangan fisik, tekanan budaya, nilai-nilai yang dianut individu dan adanya aspirasi individu. ${ }^{2}$ Hurlock mengistilahkan tugas perkembangan sebagai social expectations atau harapan sosial. ${ }^{3}$ Dikatakan sebagai harapan sosial karena setiap kelompok budaya pasti mengharapkan anggotanya mampu menguasai beberapa keterampilan tertentu yang penting dan memperoleh pola perilaku yang disetujui dalam setiap rentang kehidupan. ${ }^{4}$ Oleh karena itu, tugas perkembangan dapat dikatakan sebagai tuntutan yang harus dipenuhi oleh setiap

\footnotetext{
${ }^{1}$ Khamim Zarkasih Saputro, "Memahami ciri dan tugas perkembangan masa remaja," Aplikasia: Jurnal Aplikasi Ilmu-ilmu Agama 17, no. 1 (2018): 25-32.

${ }^{2}$ Elida Prayitno, Psikologi Perkembangan Remaja (Padang: UNP, 2002); Rini Hildayani dkk., "Psikologi perkembangan anak," 2014.

3 Elizabeth B Hurlock, Psikologi Perkembangan, Suatu Pendekatan Sepanjang Rentang Kebidupan (Jakarta: Erlangga, 1991).

${ }^{4}$ Gatot Marwoko, "Psikologi Perkembangan Masa Remaja," Tasyri: Jurnal TarbiyahSyariah-Islamiyah 26, no. 1 (2019): 60-75; Miftahul Jannah, "Remaja dan tugas-tugas perkembangannya dalam Islam,” Psikoislamedia: Jurnal Psikologi 1, no. 1 (2017).
} 
individu baik dalam bentuk sikap maupun tingkah laku sebagai konsekuensi dari adanya pertumbuhan, perkembangan dan harapan sosial.

Individu pada setiap fase perkembangan memiliki tugas perkembangan yang harus dipenuhi. Ketercapaian tugas perkembangan akan membawa dampak positif bagi individu, baik secara psikis maupun fisik. Secara psikis, individu yang mampu menguasai tugas perkembangan akan merasa senang dan bahagia, sedangkan secara fisik dapat mempermudah individu dalam menguasai tugas perkembangan berikutnya. ${ }^{5}$ Kegagalan dalam penguasaan tugas perkembangan, mengakibatkan individu mengalami ketidakbahagiaan, menimbulkan rasa tidak percaya diri, penolakan masyarakat bahkan akan mengalami kesulitan dalam penguasaan tugas-tugas perkembangan berikutnya. ${ }^{6}$

Salah satu fase perkembangan yang dilalui setiap orang adalah masa dewasa awal. Ditinjau dari segi usia, masa dewasa awal para pakar memiliki pandangan yang berbeda. Ada yang mengatakan usia dewasa awal berada pada usia 18/19 sampai 29/30 tahun. ${ }^{7}$ Pendapat lain menyatakan, masa dewasa awal berada pada usia 19-22 tahun. ${ }^{8}$ Hurlock menjelaskan masa dewasa awal berkisar usia 18 sampai 40 tahun, masa ini disebut juga masa dewasa dini. ${ }^{9}$ Walaupun demikian, para pakar sepakat bahwa pada masa dewasa awal memiliki karakteristik dan beberapa tugas perkembangan relatif sama yang harus dipenuhi oleh setiap orang. ${ }^{10}$

Pakar psikologi perkembangan mengungkapkan, tugas perkembangan dewasa awal pada umumnya terkait dengan pemenuhan berbagai tuntutan dan harapan masyarakat. ${ }^{11}$ Pada masa dewasa awal, individu sudah mulai adanya tuntutan untuk mendapatkan dan beradaptasi dengan karier dan pekerjaan. ${ }^{12}$ Selain itu sudah ada keinginan untuk memilih pasangan hidup, belajar hidup bersama pasangan dalam sebuah keluarga baik sebagai suami atau istri, mengelola kehidupan rumah tangga, belajar melaksanakan tanggung jawab

${ }^{5}$ Jihad Pamungkas Putera, "Psikologi Perkembangan," 2011.

'Pupu Saeful Rahmat, Perkembangan peserta didik (Bumi Aksara, 2021); Elida Prayitno, Perkembangan Peserta Didik (Jakarta: Dirjen Dikti, 1999).

${ }^{7}$ Prayitno, Perkembangan Peserta Didik.

${ }^{8}$ John. W Santrock, Life Span Development: Perkembangan Masa Hidup Jilid II Jakarta: Erlangga, 2015).

${ }^{9}$ Hurlock, Psikologi Perkembangan, Suatu Pendekatan Sepanjang Rentang Kebidupan.

10 Aji Bagus Priyambodo dan Hendi Setyawan, "Problematika Sosial Mahasiswa di Universitas Negeri Malang Ditinjau Dari Perspektif Perkembangan Psikososial," dalam Prosiding Seminar Nasional \& Call Paper Psikologi Sosial, 2019.

11 Agus Wibowo, Nurul Atieka, dan Hadi Pranoto, "Peningkatan Kapasistas Konselor di Perguruan Tinggidalam Kompleksitas Problematika Mahasiswa," dalam Prosiding Seminar Nasional Bimbingan dan Konseling di Perguruan Tinggi Bandung, vol. 6, 2018.

12 Rina Nurhudi Ramdhani, Amin Budiamin, dan Nandang Budiman, "Adaptabilitas Karir Dewasa Awal," Jurnal Penelitian Pendidikan 18, no. 3 (2019): 361-70. 
sebagai suami atau istri dan melaksanakan tanggung jawab sebagai orang tua, ${ }^{13}$ melakukan tanggung jawab sebagai anggota masyarakat dan warga negara, menemukan serta menjalin interaksi dengan kelompok sosial yang menyenangkan di lingkungan masyarakat. ${ }^{14}$ Untuk dapat menguasai tugas perkembangan pada masa dewasa awal diperlukan perubahan besar, baik perubahan sikap maupun perilaku. ${ }^{15}$ Akibatnya, tidak semua individu baik lakilaki dan perempuan dapat memenuhi semua harapan dalam penguasaan tugas perkembangan pada masa dewasa awal ini, bahkan ditemukan diantaranya ada yang mengalami keterlambatan dalam kematangan. ${ }^{16}$

Beberapa tugas perkembangan pada masa dewasa awal yang mesti dikuasai mencakup beberapa aspek, yaitu "aspek landasan hidup religius, landasan perilaku etis, kematangan emosional, kematangan intelektual, kesadaran tanggung jawab, peran sosial sebagai pria atau wanita, penerimaan diri dan pengembangannya, kemandirian perilaku ekonomi, wawasan dan persiapan karier, kematangan hubungan dengan teman sebaya, dan persiapan diri untuk pernikahan dan hidup berkeluarga" ${ }^{17}$ Pendapat lain menjelaskan, beberapa tugas perkembangan dewasa awal pada dasarnya lebih menekankan pada kesadaran, tanggung jawab dan kemampuan menjalankan peran sosial yang diberikan kepadanya. ${ }^{18}$ Kesadaran, tanggung jawab dan kemampuan tersebut dapat berbentuk berbagai peran sosial yang diberikan kepadanya, bertanggung jawab terhadap keluarga dan pekerjaan yang diembannya, dan semakin meningkatnya nilai keberagamaan yang dianutnya. ${ }^{19}$

Mahasiswa jika dilihat dari segi usia berada pada masa dewasa awal, secara alamiah memiliki beberapa tugas perkembangan yang harus dipenuhi. ${ }^{20}$

13 Deasy Yunika Khairun dan Meila Dwi Nurmala, "Program Bimbingan dan Konseling Mahasiswa FKIP Untirta Berbantuan Software Analisis Tugas Perkembangan,” Jurnal Penelitian Bimbingan dan Konseling 5, no. 1 (2020).

${ }^{14}$ Qudsi Iftikar Wahyudhi, Tulus Winarsunu, dan Sofa Amalia, "Kematangan sosial dan problem focused coping pada laki-laki usia dewasa awal," Jurnal Ilmiah Psikologi Terapan 7, no. 1 (2019): 52-64.

${ }^{15}$ Faricha Maulidya dan Mirta Adelina, "Periodesasi Perkembangan Dewasa," Periodesasi Perkembangan Dewasa, 2018, 1-10.

${ }^{16}$ Icha Herawati dan Ahmad Hidayat, "Quarterlife Crisis Pada Masa Dewasa Awal di Pekanbaru," Journal An-Nafs: Kajian Penelitian Psikologi 5, no. 2 (2020): 145-56.

${ }_{17}$ Sunaryo Kartadinata dan dkk, Petunjuk Teknis Penggunaan Inventori Tugas Perkembangan Mahasiswa (ITP-PT) (Bandung: UPI, 2003); Safitri Safitri, "Gambaran Tugas Perkembangan Mahasiswa Psikologi Universitas Esa Unggul," Jurnal Psikologi: Media Ilmiah Psikologi 16, no. 1 (2018).

18 Anna Erpiana dan Endang Fourianalistyawati, "Peran trait mindfulness terhadap psychological well-being pada dewasa awal," Psympathic: Jurnal Ilmiah Psikologi 5, no. 1 (2018): 6782.

19 Wahyudhi, Winarsunu, dan Amalia, "Kematangan sosial dan problem focused coping pada laki-laki usia dewasa awal."

${ }^{20}$ Wenny Hulukati dan Moh Rizki Djibran, "Analisis tugas perkembangan mahasiswa fakultas ilmu pendidikan universitas negeri gorontalo," Bikotetik. (Bimbingan Dan Konseling: Teori Dan Praktik) 2, no. 1 (2018): 73-80. 
Penguasaan tugas perkembangan ini sangat penting untuk dilakukan, sebab hal ini dapat mempengaruhi mahasiswa dalam penyesuaian diri dalam berbagai hal. ${ }^{21}$ Misalnya pencapaian kematangan intelektual akan membantu mahasiswa dalam menjalani proses perkuliahan dengan baik, perencanaan karier sesuai dengan potensi yang dimilikinya dan sebagainya. Begitu juga kesadaran tentang agama dan keyakinan yang dianutnya akan mempengaruhi upaya untuk mempelajari, memahami dan mengamalkan ajaran agamanya. ${ }^{22}$ Kemampuan dalam memilih pasangan hidup, akan mempengaruhi dalam kehidupan berumah tangga, kemampuan dalam memahami dan melaksanakan tanggung jawab akan mempengaruhi dalam menjalankan tanggung jawabnya sebagai suami, istri, orang tua warga negara dan menjalankan perannya dalam kehidupan sosial. ${ }^{23}$

Tingkat penguasaan tugas-tugas perkembangan pada pada masa awal, akan berpengaruh terhadap keberhasilan individu dalam menjalani kehidupan pada masa setengah baya, baik dalam bidang pekerjaan, karier, kehidupan dalam keluarga maupun dalam pengakuan sosial. ${ }^{24}$ Selain itu akan berpengaruh pada tingkat kepuasan dan kebahagiaan individu pada saat itu atau pada tahun-tahun terakhir kehidupannya. ${ }^{25}$ Kemampuan individu dalam penguasaan tugas perkembangan pada fase ini sangat ditentukan oleh efisiensi fisik, kemampuan motorik, kemampuan mental, motivasi dan model peran. ${ }^{26}$

Loevinger menjelaskan penguasaan tugas perkembangan mahasiswa dapat dibagi menjadi 7 tujuh tingkatan, yaitu, tingkat impulsif, perlindungan diri,

21 Alifia Fernanda Putri, "Pentingnya orang dewasa awal menyelesaikan tugas perkembangannya," SCHOULID: Indonesian Journal of School Counseling 3, no. 2 (2019): 35-40; Vertika Panggayuh, "Pengaruh kemampuan metakognitif terhadap prestasi akademik mahasiswa pada mata kuliah pemrograman dasar," JIPI (Jurnal Ilmiah Penelitian Dan Pembelajaran Informatika) 2, no. 1 (2017).

22 Zakaria Ansoriy, “Kebiasaan Membaca Al Qur'an dan Implikasinya Terhadap Kecerdasan Intelektualitas Mahasiswa," OSF Preprints, 2021.

${ }^{23}$ Vania Utami dan Lukmanul Hakim, "Hubungan Harga Diri Dengan Kecemasan Memilih Pasangan Hidup Pada Perempuan Dewasa Awal,” Jurnal Psimawa 2, no. 1 (2019): 15-20; Nenden Ineu Herawati, "Mengembangkan Program Layanan Bimbingan dan Konseling untuk Meningkatkan Tugas Perkembangan Mahasiswa Upi Kampus Cibiru," Cakrawala Dini: Jurnal Pendidikan Anak Usia Dini 6, no. 1 (2018).

24 Miftahul Jannah, Siti Rozaina Kamsani, dan Nurhazlina Mohd Ariffin, "Perkembangan Usia Dewasa: Tugas dan Hambatan pada Korban Konflik Pasca Damai," Bunayya: Jurnal Pendidikan Anak 8, no. 2 (2021): 114-43; Priyambodo dan Setyawan, "Problematika Sosial Mahasiswa di Universitas Negeri Malang Ditinjau Dari Perspektif Perkembangan Psikososial."

25 Aisah Indati, "Konsep Kearifan pada Dewasa Awal, Tengah, dan Akhir," psychologyforum.umm.ac.id Prosiding Temilnas XI IPPI (20 September 2019); Sindhy Mariam Magdalena Pello dan Christiana Hari Soetjiningsih, "Kebahagiaan pada Wanita Dewasa Madya yang Melajang," Psikologi Konseling 16, no. 1 (2020).

26 Hurlock, Psikologi Perkembangan, Suatu Pendekatan Sepanjang Rentang Kehidupan; Santrock, Life Span Development: Perkembangan Masa Hidup Jilid II. 
konformistik, sadar diri, saksama, individualistic dan otonomi. ${ }^{27}$ Ketujuh tingkatan perkembangan tersebut dapat digunakan untuk mendeskripsikan keberadaan individu pada tingkat mana dalam penguasaan tugas-tugas perkembangan. ${ }^{28}$ Setiap tingkat perkembangan dibangun atas dasar tingkat perkembangan sebelumnya. Tingkat perkembangan yang dikuasai oleh setiap individu menjadi dasar bagi penguasaan tingkat perkembangan berikutnya. ${ }^{29}$ Tingkat penguasaan tugas-tugas perkembangan mahasiswa diukur mulai dari tingkat sadar diri, saksama, individualitas hingga tahap otonomi. ${ }^{30}$

Berdasarkan studi awal yang dilakukan pada terhadap mahasiswa Fakultas Tarbiyah Institut Agama Islam Negeri (IAIN) Curup, beberapa mahasiswa kuliah hanya karena faktor kebetulan karena tidak lulus pada perguruan tinggi yang lain. Dalam memilih program studi tanpa melalui perencanaan yang matang. Akibatnya adalah mahasiswa kurang mampu menyesuaikan diri dalam proses perkuliahan dan Indeks Prestasi (IP) yang rendah. Jika hal ini dikaitkan dengan tugas perkembangan, salah satu penyebabnya adalah individu kurang mampu menguasai tugas-tugas perkembangan khususnya berkaitan dengan perencanaan karier dan mempersiapkan diri menghadapi pernikahan dan hidup berkeluarga.

Melihat kenyataan tersebut, penguasaan tugas perkembangan mahasiswa perlu diketahui sehingga memudahkan dalam memberikan bimbingan. Bimbingan dapat dilakukan oleh Penasihat Akademik dan pusat kajian tertentu yang mempunyai peran menangani pelayanan kepada mahasiswa. Salah satu pusat kajian tersebut adalah Pusat Student Carrier. Kenyataannya adalah Penasihat Akademik dan Pusat Student Carrier dalam memberikan bimbingan kepada mahasiswa belum sampai menyentuh penguasaan tugas-tugas perkembangan mahasiswa. Oleh karena itu perlu dilakukan pengukuran terhadap tingkat penguasaan tugas perkembangan pada mahasiswa, sehingga dapat membantu merumuskan kondisi objektif terhadap tugas-tugas perkembangan yang belum dikuasai mahasiswa. Dengan adanya kajian ini diharapkan dapat mempermudah Penasihat Akademik maupun Pusat Student Carrier IAIN Curup merumuskan program kegiatan dalam memberikan pelayanan kepada mahasiswa.

Kajian ini akan mendeskripsikan tingkat penguasaan tugas perkembangan mahasiswa Fakultas Tarbiyah IAIN Curup dengan menggunakan pendekatan kuantitatif yang bersifat deskriptif. ${ }^{31}$. Populasi penelitian dalam ini

27 Ravenna M. Helson dan Valory Mitchell, "8. Loevinger's Theory of Ego Development," dalam Women on the River of Life (University of California Press, 2020), 113-26.

28 Kartadinata dan dkk, Petunjuk Teknis Penggunaan Inventori Tugas Perkembangan Mahasiswa (ITP-PT).

${ }^{29}$ Hurlock, Psikologi Perkembangan, Suatu Pendekatan Sepanjang Rentang Kebidupan.

30 Kartadinata dan dkk, Petunjuk Teknis Penggunaan Inventori Tugas Perkembangan Mahasiswa (ITP-PT).

31 Sugiono, Metode penelitian pendidikan: Pendekatan kuantitatif, kualitatif dan $\mathrm{R} \& \mathrm{D}$, (Bandung: Alfabeta, 2019); Nazir, Metode Penelitian (Bogor: Ghalia Indonesia, 2015). 
adalah mahasiswa Program Sarjana (S1) Fakultas Tarbiyah Institut Agama Islam Negeri yang terdiri dari mahasiswa Program Studi Pendidikan Agama Islam (PAI), Bimbingan Konseling Pendidikan Islam (BKPI), Tadris Pendidikan Bahasa Inggris (TPBI), dan Pendidikan Bahasa Arab (PBA) adalah berjumlah 1.133. Sampel adalah sebagian populasi yang diteliti, ${ }^{32}$ yang berjumlah 126 orang, PAI 30 orang, PGMI 30 orang, BKPI 25 orang, TBI 25 orang dan PBA 16 orang. Teknik pengambilan sampel dalam penelitian ini adalah Cluster random sampling yaitu pengambilan sampel dengan cara memilih salah satu kelompok secara acak tanpa memperhatikan strata yang ada dalam populasi. ${ }^{33}$ Dalam penelitian ini penulis memilih satu lokal setiap Program Studi yang menjadi populasi penelitian secara acak untuk dijadikan sampel penelitian.

Alat pengumpulan data yang digunakan adalah Inventori Tugas Perkembangan Mahasiswa (ITP-PT) yang dikembangkan oleh Sunaryo Kartadinata dkk. Iventori Tugas Perkembangan Mahasiswa (ITP-PT), yaitu instrumen yang digunakan untuk memahami tingkat perkembangan individu. ${ }^{34}$ Instrumen ini sudah berstandar dan telah diuji secara empirik dengan tingkat reliabilitas dan validitas sedang. Inventori tersebut digunakan untuk mengukur tingkat penguasaan tugas-tugas perkembangan mahasiswa, yang mencakup sebelas aspek perkembangan, yaitu:

Tabel 1

Indikator Tugas Perkembangan Mahasiswa

\begin{tabular}{lll}
\hline \multicolumn{1}{c}{ Variabel } & \multicolumn{1}{c}{ Indikator } & \multicolumn{1}{c}{ Sub Indikator } \\
\hline & Landasan hidup & - Melaksanakan shalat dan berdoa \\
& religious & - Belajar agama \\
& & - Iman \\
& & - Sabar \\
\cline { 2 - 3 } & Landasan & - Kejujuran \\
& perilaku etis & - Berbakti kepada orang tua \\
& & - Akhlak dan solan santun \\
& & - Kepatuhan dan ketertiban \\
\cline { 2 - 3 } Tugas & Kematangan & - Kebebasan menyampaikan pendapat \\
Mahasiswa & emosional & - Ketenangan \\
& & - Kemampuan mengendalikan emosi \\
& & - Kemampuan menjaga stabilitas \\
& & emosi \\
\cline { 2 - 3 } & Kematangan & - Kritis \\
\hline
\end{tabular}

32 John W. Creswell, Research Designi: Pendekatan Metode Kualitatif, Kuantitatif dan Campuran (Yogyakarta: Pustaka Pelajar, 2017); Syahron Lubis, Metodologi Penelitian Kuantitatif (Padang: UNP P, 2003).

${ }^{33}$ Lubis, Metodologi Penelitian Kuantitatif.

34 Kartadinata dan dkk, Petunjuk Teknis Penggunaan Inventori Tugas Perkembangan Mahasiswa (ITP-PT). 


\begin{tabular}{|c|c|}
\hline intelektual & $\begin{array}{l}\text { - Rasional } \\
\text { - Mampu membela hak pribadi } \\
\text { - Mampu menilai }\end{array}$ \\
\hline $\begin{array}{l}\text { Peran sosial } \\
\text { sebagai pria atau } \\
\text { Wanita }\end{array}$ & $\begin{array}{l}\text { - Penampilan sesuai jenis kelamin } \\
\text { - Menjalankan peran sosial sesuai jenis } \\
\text { kelamin } \\
\text { - Memiliki cita-cita sesuai jenis } \\
\text { kelamin }\end{array}$ \\
\hline $\begin{array}{l}\text { Penerimaan diri } \\
\text { dan } \\
\text { pengembangann } \\
\text { ya }\end{array}$ & $\begin{array}{l}\text { - Keadaan fisik } \\
\text { - Keadaan psikis atau mental } \\
\text { - Mengembangkan cita-cita }\end{array}$ \\
\hline $\begin{array}{l}\text { Kemandirian } \\
\text { prilaku ekonomi }\end{array}$ & $\begin{array}{l}\text { - Menghasilkan uang } \\
\text { - Hemat dan suka menabung } \\
\text { - Ulet dan memiliki kemauan yang } \\
\text { kuat } \\
\text { - Tidak berpangku tangan }\end{array}$ \\
\hline $\begin{array}{l}\text { Wawasan } \\
\text { persiapan karir }\end{array}$ & $\begin{array}{l}\text { - Memahami jenis pekerjaan } \\
\text { - Rajin belajar } \\
\text { - Bisa merencanakan karir } \\
\text { - Meningkatkan keterampilan dan } \\
\text { keahlian }\end{array}$ \\
\hline $\begin{array}{l}\text { Kematangan } \\
\text { hubungan } \\
\text { dengan teman }\end{array}$ & $\begin{array}{l}\text { - Memahami orang lain } \\
\text { - Bisa berempati } \\
\text { - Dapat bekerja sama } \\
\text { - Dapat berinteraksi dengan teman }\end{array}$ \\
\hline $\begin{array}{l}\text { Persiapan diri } \\
\text { untuk } \\
\text { pernikahan dan } \\
\text { hidup } \\
\text { berkeluarga }\end{array}$ & $\begin{array}{l}\text { - Mampu memilih pasangan hidup } \\
\text { - Siap untuk menikah } \\
\text { - Kesiapan membangun rumah tangga } \\
\text { - Kesehatan reproduksi }\end{array}$ \\
\hline
\end{tabular}

Inventory Tugas Perkembangan mahasiswa (ITP-PT) terdiri dari 77 butir. Setelah diskor, 11 butir menunjukkan tingkat konsistensi jawaban responden dan 66 butir menunjukkan tingkat perkembangan subjek dalam sebelas aspek perkembangan. Adapun kriteria penyekoran yang digunakan untuk menentukan tingkat ketercapaian tugas perkembangan sebagai berikut:

Tabel 2

Kriteria Penyekoran Aspek Perkembangan

\begin{tabular}{ccl}
\hline Skor & Kode & \multicolumn{1}{c}{ Tingkat Perkembangan } \\
\hline 4 & SDI & Tahap Sadar Diri \\
\hline 5 & SAK & Tahap Saksama \\
\hline
\end{tabular}




\begin{tabular}{lll}
\hline 6 & IND & Tahap Individualitas \\
\hline 7 & OTO & Tahap Otonomi \\
\hline
\end{tabular}

Pertimbangan peneliti menggunakan instrumen ini adalah, karena penelitian ini bertujuan untuk mengetahui tingkat penguasaan tugas-tugas perkembangan pada mahasiswa Program Sarjana (S1) Fakultas Tarbiyah, maka instrumen tersebut sangat cocok digunakan, sebab instrumen tersebut secara khusus disusun untuk mengukur tingkat penguasaan tugas-tugas perkembangan mahasiswa dan sudah diuji secara empirik. Teknik analisis data yang digunakan adalah analisis deskriptif dengan perhitungan persentase terhadap data nominal. ${ }^{35}$

\section{Hasil dan Pembahasan}

Tingkat ketercapaian tugas perkembangan mahasiswa Fakultas Tarbiyah secara keseluruhan rata-rata sebesar 6.73 dengan rata-rata konsistensi terhadap penguasaan tugas perkembangan 6.51. Simpangan baku 0.10 dan koefisien variasi $2.78 \%$. Tingkat pencapaian tugas perkembangan berdasarkan aspek sebagai berikut:

Tabel 3

Tingkat Penguasaan Tugas Perkembangan Mahasiswa Fakultas Tarbiyah

\begin{tabular}{llll}
\hline No. & \multicolumn{1}{c}{ ASPEK } & SKOR & TINGKAT \\
\hline 1. & Landasan hidup religious & 6.86 & Individualitas \\
\hline 2. & Landasan perilaku etis & 6.61 & Individualitas \\
\hline 3. & Kematangan emosional & 6.64 & Individualitas \\
\hline 4. & Kematangan intelektual & 6.64 & Individualitas \\
\hline 5. & Kesadaran tanggung jawab & 6.89 & Individualitas \\
\hline 6. & Peran sosial sebagai pria dan wanita & 6.72 & Individualitas \\
\hline 7. & Penerimaan diri dan pengembangannya & 6.87 & Individualitas \\
\hline 8. & Kemandirian perilaku ekonomis & 6.74 & Individualitas \\
\hline 9. & Wawasan dan persiapan karier & 6.77 & Individualitas \\
\hline 10. & Kematangan hubungan dengan teman sebaya & 6.74 & Individualitas \\
\hline 11. & $\begin{array}{l}\text { Persiapan diri untuk pernikahan dan hidup } \\
\text { berkeluarga }\end{array}$ & & Individualitas \\
\hline
\end{tabular}

\section{Tingkat Pencapaian Tugas Perkembangan Mahasiswa Program Studi PAI}

Tingkat pencapaian tugas perkembangan mahasiswa program studi Pendidikan Agama Islam (PAI) rata-rata 6.80, dengan rata-rata konsistensi terhadap penguasaan tugas perkembangan 5.78. Simpangan baku 0.13 dan

${ }^{35}$ Ridwan, Dasar-dasar Statistike (Bandung: Alfabeta, 2017). 
koefisien variasi $3.40 \%$. Tingkat pencapaian tugas perkembangan berdasarkan aspek sebagai berikut:

Tabel 4

Tingkat Penguasaan Tugas Perkembangan Mahasiswa PAI

\begin{tabular}{llll}
\hline No. & \multicolumn{1}{c}{ ASPEK } & SKOR & TINGKAT \\
\hline 1. & Landasan hidup religious & 6.82 & Individualitas \\
\hline 2. & Landasan perilaku etis & 6.68 & Individualitas \\
\hline 3. & Kematangan emosional & 6.67 & Individualitas \\
\hline 4. & Kematangan intelektual & 6.62 & Individualitas \\
\hline 5. & Kesadaran tanggung jawab & 7.04 & Otonomi \\
\hline 6. & Peran sosial sebagai pria dan wanita & 6.84 & Individualitas \\
\hline 7. & Penerimaan diri dan pengembangannya & 6.91 & Individualitas \\
\hline 8. & Kemandirian perilaku ekonomis & 6.74 & Individualitas \\
\hline 9. & Wawasan dan persiapan karier & 6.89 & Individualitas \\
\hline 10. & Kematangan hubungan dengan teman sebaya & 6.91 & Individualitas \\
\hline 11. & $\begin{array}{l}\text { Persiapan diri untuk pernikahan dan hidup } \\
\text { berkeluarga }\end{array}$ & & Individualitas \\
\hline
\end{tabular}

Tingkat Pencapaian Tugas Perkembangan Mahasiswa Program Studi PGMI

Rata-rata tingkat pencapaian tugas perkembangan mahasiswa PGMI 6.63 dengan rata-rata konsistensi terhadap penguasaan tugas perkembangan 7.18. Simpangan baku 0.13 dan koefisien variasi 3.67\%. Tingkat pencapaian tugas perkembangan berdasarkan aspek sebagai berikut:

\section{Tabel 5}

Tingkat Penguasaan Tugas Perkembangan Mahasiswa PGMI

\begin{tabular}{llll} 
No. & \multicolumn{1}{c}{ ASPEK } & SKOR & \multicolumn{1}{c}{ TINGKAT } \\
\hline 1. & Landasan hidup religious & 6.71 & Individualitas \\
\hline 2. & Landasan perilaku etis & 6.54 & Individualitas \\
\hline 3. & Kematangan emosional & 6.50 & Individualitas \\
\hline 4. & Kematangan intelektual & 6.67 & Individualitas \\
\hline 5. & Kesadaran tanggung jawab & 6.86 & Individualitas \\
\hline 6. & Peran sosial sebagai pria dan wanita & 6.73 & Individualitas \\
\hline 7. & Penerimaan diri dan pengembangannya & 6.79 & Individualitas \\
\hline 8. & Kemandirian perilaku ekonomis & 6.66 & Individualitas \\
\hline 9. & Wawasan dan persiapan karier & 6.45 & Individualitas \\
\hline 10. & $\begin{array}{l}\text { Kematangan hubungan dengan teman } \\
\text { sebaya }\end{array}$ & 6.53 & Individualitas \\
\hline 11. & $\begin{array}{l}\text { Persiapan diri untuk pernikahan dan hidup } \\
\text { berkeluarga }\end{array}$ & & \\
\hline
\end{tabular}


Tingkat Pencapaian Tugas Perkembangan Mahasiswa Program Studi BKPI

Tingkat pencapaian tugas perkembangan mahasiswa Bimbingan Konseling Pendidikan Islam (BKPI) Fakultas Tarbiyah dengan rata-rata 6.78 dengan rata-rata konsistensi terhadap penguasaan tugas perkembangan 7.30. Simpangan baku 0.13 dan koefisien variasi $3.48 \%$. Tingkat pencapaian tugas perkembangan berdasarkan aspek sebagai berikut:

Tabel 6

Tingkat Penguasaan Tugas Perkembangan Mahasiswa BKPI

\begin{tabular}{llll}
\hline No. & \multicolumn{1}{c}{ ASPEK } & SKOR & TINGKAT \\
\hline 1. & Landasan hidup religious & 6.94 & Individualitas \\
\hline 2. & Landasan perilaku etis & 6.67 & Individualitas \\
\hline 3. & Kematangan emosional & 6.59 & Individualitas \\
\hline 4. & Kematangan intelektual & 6.80 & Individualitas \\
\hline 5. & Kesadaran tanggung jawab & 7.03 & Otonomi \\
\hline 6. & Peran sosial sebagai pria dan wanita & 6.74 & Individualitas \\
\hline 7. & Penerimaan diri dan pengembangannya & 6.66 & Individualitas \\
\hline 8. & Kemandirian perilaku ekonomis & 6.88 & Individualitas \\
\hline 9. & Wawasan dan persiapan karier & 6.70 & Individualitas \\
\hline 10. & Kematangan hubungan dengan teman sebaya & 6.81 & Individualitas \\
\hline 11. & $\begin{array}{l}\text { Persiapan diri untuk pernikahan dan hidup } \\
\text { berkeluarga }\end{array}$ & 6.74 & Individualitas \\
\hline
\end{tabular}

Tingkat Pencapaian Tugas Perkembangan Mahasiswa Program Studi TBI

Rata-rata tingkat pencapaian tugas perkembangan mahasiswa Tadris Bahasa Inggris Fakultas Tarbiyah IAIN Curup 6.72 dengan rata-rata konsistensi terhadap penguasaan tugas perkembangan 6.72 . Simpangan baku 0.22 dan koefisien variasi $5.95 \%$. Tingkat pencapaian tugas perkembangan berdasarkan aspek sebagai berikut:

Tabel 7

Tingkat Penguasaan Tugas Perkembangan Mahasiswa PGMI

\begin{tabular}{llll}
\hline No. & \multicolumn{1}{c}{ ASPEK } & SKOR & TINGKAT \\
\hline 1. & Landasan hidup religious & 7.01 & Otonimi \\
\hline 2. & Landasan perilaku etis & 6.48 & Individualitas \\
\hline 3. & Kematangan emosional & 6.63 & Individualitas \\
\hline 4. & Kematangan intelektual & 6.44 & Individualitas \\
\hline 5. & Kesadaran tanggung jawab & 6.69 & Individualitas \\
\hline 6. & Peran sosial sebagai pria dan wanita & 6.57 & Individualitas \\
\hline 7. & Penerimaan diri dan pengembangannya & 7.16 & Otonomi \\
\hline 8. & Kemandirian perilaku ekonomis & 6.82 & Individualitas \\
\hline
\end{tabular}




\begin{tabular}{llll}
\hline 9. & Wawasan dan persiapan karier & 6.84 & Individualitas \\
\hline 10. & Kematangan hubungan dengan teman sebaya & 6.67 & Individualitas \\
\hline 11. & $\begin{array}{l}\text { Persiapan diri untuk pernikahan dan hidup } \\
\text { berkeluarga }\end{array}$ & & Individualitas \\
\hline
\end{tabular}

\section{Tingkat Pencapaian Tugas Perkembangan Mahasiswa Program Studi PBA}

Tingkat pencapaian tugas perkembangan mahasiswa Pendidikan Bahasa Arab (PVA) Fakultas Tarbiyah IAIN Curup rata-rata sebesar 6.78 dengan ratarata konsistensi terhadap penguasaan tugas perkembangan 5.89. Simpangan baku 0.12 dan koefisien variasi $3.20 \%$. Tingkat pencapaian tugas perkembangan berdasarkan aspek sebagai berikut:

Tabel 8

Tingkat Penguasaan Tugas Perkembangan Mahasiswa BKPI

\begin{tabular}{llcl}
\hline No. & \multicolumn{1}{c}{ ASPEK } & SKOR & TINGKAT \\
\hline 1. & Landasan hidup religious & 6.87 & Individualitas \\
\hline 2. & Landasan perilaku etis & 6.66 & Individualitas \\
\hline 3. & Kematangan emosional & 6.76 & Individualitas \\
\hline 4. & Kematangan intelektual & 6.64 & Individualitas \\
\hline 5. & Kesadaran tanggung jawab & 6.78 & Individualitas \\
\hline 6. & Peran sosial sebagai pria dan wanita & 6.66 & Individualitas \\
\hline 7. & Penerimaan diri dan pengembangannya & 6.84 & Individualitas \\
\hline 8. & Kemandirian perilaku ekonomis & 6.64 & Individualitas \\
\hline 9. & Wawasan dan persiapan karier & 6.93 & Individualitas \\
\hline 10. & Kematangan hubungan dengan teman sebaya & 6.73 & Individualitas \\
\hline 11. & Persiapan diri untuk pernikahan dan hidup & 6.52 & Individualitas \\
& berkeluarga & & \\
\hline
\end{tabular}

Berdasarkan hasil analisis data dapat diketahui bahwa rata-rata pencapaian tugas perkembangan mahasiswa Fakultas Tarbiyah IAIN Curup 6.73 Ini berarti bahwa rata-rata tingkat pencapaian tugas perkembangan berada pada tingkat individualitas. Dilihat dari jumlah skor, tingkat pencapaian tugas perkembangan pada tidak jauh berbeda antara aspek perkembangan yang satu dengan aspek perkembangan lainnya. Pencapaian tingkat perkembangan yang paling tinggi dicapai oleh mahasiswa pada aspek kesadaran tanggung jawab sebesar 6.89, dan terendah tentang landasan perilaku etis sebesar 6.65 .

Jika dilihat pada setiap aspek perkembangan pada setiap program studi, nilai rata-rata semuanya berada pada tingkatan yang sama, yaitu berada pada tingkat individualitas. Namun ada berberapa aspek tugas perkembangan untuk mahasiswa program studi PAI dan BKPI yang sudah mencapai tingkat otonomi, yaitu aspek kesadaran tanggung jawab dengan skor 7.04 dan 7.03 dan mahasiswa TBI pada aspek landasan hidup religious dan penerimaan diri serta 
pengembangannya juga sudah mencapai tingkat otonomi dengan skor 7.01 dan 7.16. Namun selebihnya masih berada pada tingkat individualitas. Adanya kesamaan pencapaian tugas perkembangan dimungkinkan karena mahasiswa Fakultas Tarbiyah IAIN Curup berada pada rentang usia yang relatif sama, yaitu 18-23 tahun. Hal ini sejalan dengan ungkapan Hurlock, individu yang berada pada rentang usia yang sama akan cenderung memiliki karakteristik yang sama, termasuk dalam pencapaian tugas perkembangan.

Loevinger menjelaskan pencapaian tugas perkembangan pada tingkat individualis mengandung makna bahwa individu sudah memiliki kesadaran tentang konflik emosional antara ketergantungan dengan keinginan mandiri dan antara mementingkan diri sendiri dengan berbagi terhadap orang lain. ${ }^{36}$ Individu yang mencapai perkembangan pada tingkat ini juga sudah mengenal dan memahami eksistensi dirinya, ${ }^{37}$ sudah menyadari bagaimana harus bersikap dan bertingkah laku, sudah memahami perbedaan antar individu dan dapat bersikap toleran terhadap pertentangan dalam kehidupan. ${ }^{38}$ Selain itu pada tingkat ini individu sudah mampu membedakan antara kehidupan internal dan kehidupan eksternal, sudah mengenal dirinya secara kolektif dan memiliki kepedulian terhadap situasi serta problematika yang terjadi di lingkungan sosial. ${ }^{39}$

Tingkat otonomi merupakan tingkatan perkembangan yang memiliki kedudukan lebih tinggi setingkat dari tingkat individual. ${ }^{40}$ Individu yang sudah mencapai tingkat perkembangan otonomi akan cenderung bersikap realistis dan objektif baik terhadap diri sendiri maupun terhadap orang lain. ${ }^{41}$ Pendapat lain menjelaskan individu yang sudah mencapai perkembangan tingkat otonomi akan memiliki sikap peduli terhadap keadilan sosial, ${ }^{42}$ mampu mengintegrasikan nilainilai yang berbeda dan memiliki keberanian untuk menyelesaikan masalah internal. ${ }^{43}$ Selain itu, individu yang telah mencapai tingkat perkembangan otonomi akan memiliki kesadaran adanya saling ketergantungan antar sesama,

${ }^{36}$ Helson dan Mitchell, "8. Loevinger's Theory of Ego Development."

${ }^{37}$ Kurnia Sari, "Korelasi Motivasi Mahasiswa dalam Mengikuti Perkuliahan Terhadap Perencanaan Karier," Jurnal Fokus Konseling 4, no. 1 (2018): 136-42.

${ }^{38}$ Helson dan Mitchell, "8. Loevinger's Theory of Ego Development."

39 Kartadinata dan dkk, Petunjuk Teknis Penggunaan Inventori Tugas Perkembangan Mahasiswa (ITP-PT).

40 Andi Agustang, "Kesejahteraan Psikologis (studi Pada Dewasa Madya Yang Belum Menikah Di Kota Makassar)," 2021.

41 Aprius Maduwita Guswani dan Fajar Kawuryan, "Perilaku agresi pada mahasiswa ditinjau dari kematangan emosi," Jurnal Psikologi UMK: PITUTUR 1, no. 2 (2011): 86-92.

${ }^{42}$ R. Anggoro Rahardjo Harry Anwar, "Peran Perguruan Tinggi dalam Pengembangan Kepedulian Sosial Mahasiswa," Sosiobumanitas 20, no. 1 (2018).

${ }^{43}$ Fitrianto Eko Subekti dan Akhmad Jazuli, "Peningkatan Kemampuan Pemecahan Masalah dan Kemandirian Belajar Mahasiswa Melalui Pembelajaran Berbasis Masalah," JNPM Jurnal Nasional Pendidikan Matematika) 4, no. 1 (2020): 13-27. 
memiliki keyakinan dalam mengekspresikan perasaan dan keyakinannya serta respek terhadap kemandirian orang lain. ${ }^{44}$

Perbedaan dan belum sempurnanya pencapaian tugas perkembangan dipengaruhi oleh banyak faktor. Di antaranya dapat dipengaruhi oleh penerimaan terhadap diri sendiri, ${ }^{45}$ lingkungan yang mendukung perkembangan ${ }^{46}$ dan kesehatan yang baik. ${ }^{47}$ Kecuali dari itu, penguasaan tugas perkembangan dipengaruhi faktor kesempatan untuk mempelajari tugas perkembangan dan bimbingan untuk menguasai dan motivasi yang kuat untuk belajar. ${ }^{48}$ Di lihat dari usianya, mahasiswa Fakultas Tarbiyah IAIN Curup baru berusia 19 atau 23 tahun. Padahal rentang fase perkembangan untuk dewasa berkisar antara 18-40 tahun. ${ }^{49}$ Ini berarti masih banyak waktu yang dimiliki oleh mahasiswa untuk menguasai tugas-tugas perkembangan ke tingkat otonomi.

Penyikapan secara tepat terhadap proses perkembangan juga dapat mempengaruhi penguasaan tugas perkembangan. ${ }^{50}$ Perubahan-perubahan yang terjadi pada individu sebagai akibat dari proses perkembangan, baik perubahan fisik maupun psikis. jika disikapi secara positif dan penuh dengan kebahagiaan, maka individu akan lebih mudah menguasai tugas-tugas perkembangan pada periode tertentu. ${ }^{51}$

Di sisi lain, penguasaan tugas-tugas perkembangan fase sebelumnya, masa kanak-kanak dan masa remaja sangat menentukan pencapaian tugas-tugas perkembangan pada masa dewasa awal. ${ }^{52}$ Erikson menjelaskan bahwa pada masa kanak-kanak merupakan gambaran awal manusia sebagai seorang manusia. ${ }^{53}$ Ini berarti bahwa pencapaian tugas-tugas perkembangan pada masa sebelumnya

44 Hulukati dan Djibran, "Analisis tugas perkembangan mahasiswa fakultas ilmu pendidikan universitas negeri gorontalo.”

45 Dessy Sumanty, Deden Sudirman, dan Diah Puspasari, "Hubungan religiusitas dengan citra tubuh pada wanita dewasa awal," Jurnal Psikologi Islam dan Budaya 1, no. 1 (2018): 928.

${ }^{46}$ Nurul Nisa dan Triana Lestari, "Pengaruh Sikap Orang Tua yang Overprotektive terhadap Perkembangan Kemandirian Anak," Jurnal Elementary : Kajian Teori dan Hasil Penelitian Pendidikan Sekolah Dasar 4, no. 2 (29 Juni 2021): 112-15, https://doi.org/10.31764/elementary.v4i2.4747; Yusup Adi Saputro dan Rini Sugiarti, "Pengaruh Dukungan Sosial Teman Sebaya dan Konsep Diri terhadap Penyesuaian Diri pada Siswa SMA Kelas X," Philanthropy: Journal of Psychology 5, no. 1 (2021): 59-72.

47 Wahyudhi, Winarsunu, dan Amalia, "Kematangan sosial dan problem focused coping pada laki-laki usia dewasa awal."

${ }^{48}$ Novita Agustina, Okvantia Nurmaisara, dan Tyas Martika Anggriana, "Upaya Meningkatkan Kematangan Pemilihan Karir melalui Bimbingan Kelompok dengan Teknik Problem Solving" 1 (2017): 6.

${ }^{49}$ Hurlock, Psikologi Perkembangan, Suatu Pendekatan Sepanjang Rentang Kebidupan.

${ }^{50}$ Putera, "Psikologi Perkembangan."

${ }^{51}$ Santrock, Life Span Development: Perkembangan Masa Hidup Jilid II.

${ }^{52}$ Nadia Nur Azizah dan Aan Asef Richval, "Pertumbuhan dan Perkembangan dalam Psikologi Perkembangan,” http:/ / eprints.umsida.ac.id/1273/, 2018, 1-13.

53 Hurlock, Psikologi Perkembangan, Suatu Pendekatan Sepanjang Rentang Kehidupan. 
sangat menentukan pencapaian tugas perkembangan pada masa selanjutnya. Apabila mahasiswa tingkat pencapaian tugas perkembangan masih rendah, ada kemungkinan hal ini disebabkan ketika pada masa kanak-kanak dan pada masa remaja ada beberapa tugas perkembangan yang belum dan tidak dapat tercapai.

Kemampuan seorang anak dalam menguasai tugas-tugas perkembangan juga sangat tergantung pada bagaimana orang tua memenuhi kebutuhan anak akan makan, perhatian dan cinta kasih. ${ }^{54}$ Sekali anak mendapatkan pelajaran yang menyenangkan, maka sikap tersebut akan mewarnai persepsi individu terhadap masyarakat dan suasana sepanjang hidupnya. ${ }^{55}$ Oleh karena itu orang tua harus mampu mengarahkan dan memberikan bimbingan kepada anaknya ke arah penyesuaian yang baik. Hal ini disebabkan karena hasil belajar dan pengalaman memainkan peran dominan dalam perkembangan anak. ${ }^{56}$ Membiarkan anak tumbuh dan mengerjakan apa yang diinginkannya akan mengakibatkan anak tidak berpengalaman untuk mengetahui apa yang diharapkan oleh masyarakat. Bimbingan orang tua sangat diperlukan ketika individu berada pada tahap awal belajar. ${ }^{57}$ Apabila sejak awal anak telah diletakkan di atas rel yang benar dan mendorong untuk tetap di sana hingga ia terbiasa dan menyadari hal itu hal itu sangat penting dan baik, maka kecil kemungkinan ia akan beralih ke rel yang salah. $^{58}$

Bimbingan dan arahan, juga dapat diberikan oleh guru di sekolah. Baik guru pembimbing maupun dari guru mata pelajaran. Guru pembimbing memberikan bimbingan melalui beberapa jenis layanan, seperti layanan informasi, penempatan dan penyaluran, konseling induvidual, bimbingan kelompok, konseling kelompok dan sebagainya. ${ }^{59}$ Pemberian arahan dan bimbingan, juga dapat diberikan oleh guru mata pelajaran. Misalnya guru Pendidikan Agama Islam, hendaknya mampu memberikan bimbingan berkaitan

${ }^{54}$ Efrianus Ruli, “Tugas dan Peran Orang Tua dalam Mendidk Anak," Jurnal Edukasi Nonformal 1, no. 2 (2020): 143-46.

55 Tukinem Tukinem, "Mendidik anak dalam perspektif Islam (Kajian syarah Riyadhush-Shalihin)," Journal of Islamic Education and Innovation 1, no. 2 (2020): 39-49.

${ }^{56}$ Nur Astuti Agustriyana dan Insan Suwanto, "Fully human being pada remaja sebagai pencapaian perkembangan identitas," Jurnal Bimbingan Konseling Indonesia 2, no. 1 (2017): 9-11.

${ }^{57}$ Lina Novita dan Anisa Agustina, "Bimbingan Orang Tua Dengan Disiplin Siswa," Pedagonal: Jurnal Ilmiah Pendidikan 2, no. 1 (2018): 1-14.

58 Jamaluddin Jamaluddin, Acep Komarudin, dan Asep Andi Rahman, "Bimbingan orang tua dalam mengembangkan kepribadian anak," Atthulab: Islamic Religion Teaching and Learning Journal 4, no. 2 (2019): 170-84; Arifudin Mahmudi, Joko Sulianto, dan Ikha Listyarini, "Hubungan Perhatian Orang Tua Terhadap Hasil Belajar Kognitif Siswa," Jurnal Pedagogi dan Pembelajaran 3, no. 1 (2020): 122-29.

${ }^{59}$ Faricha Azizah, Fitri Br Ginting, dan Robbi Suraida Utami, "Evaluasi Pelaksanaan Program Layanan Bimbingan dan Konseling di Sekolah," dalam Prosiding Seminar Bimbingan dan Konseling, vol. 1, 2017, 177-88. 
dengan landasan hidup religius, perilaku etis dan sebagainya. ${ }^{60}$ Guru mata pelajaran lain juga dapat memberikan arahan dan bimbingan dalam membantu siswa untuk penguasaan tugas-tugas perkembangan. ${ }^{61}$

Proses belajar juga mempengaruhi pencapaian tingkat perkembangan. Belajar dapat dilakukan melalui latihan dan usaha. Melalui belajar, individu akan memperoleh kemampuan memahami dan melaksanakan sumber-sumber yang diwariskan, seperti landasan religius, prilaku etis dan sebagainya. ${ }^{62}$ Proses belajar dapat terjadi secara imitasi, yaitu secara sadar atau tidak sadar meniru apa yang dilihat atau dilakukan oleh orang lain, baik di lingkungan keluarga, sekolah maupun masyarakat. ${ }^{63}$ Belajar juga dapat dilakukan melalui proses latihan, seperti kebiasaan melaksanakan puasa, salat, bersedekah, berkata baik, menolong sesama dan sebagainya. ${ }^{64}$ Belajar juga dapat dilakukan dengan cara peningkatan wawasan dan pengalaman melalui membaca buku-buku berkaitan pencapaian tugas-tugas perkembangan. ${ }^{65}$ Misalnya, membaca buku-buku agama dapat meningkatkan wawasan berkaitan dengan landasan hidup religius. Berbagi sesama dan menghargai teman, kesemuanya itu dapat dilakukan melalui proses belajar.

Tipe pelayanan orang tua juga dapat mempengaruhi tingkat pencapaian tugas perkembangan individu. Tipe pelayanan orang tua kepada anak dapat dikelompokkan menjadi beberapa tipe. Pertama, tipe hangat. Orang tua yang memiliki tipe pelayanan ini selalu perhatian, mencurahkan kasih sayang, memberikan kesempatan anaknya untuk berekspresi dan selalu mendukung semua kegiatan anak yang bersifat positif. ${ }^{66}$ Anak yang dibesarkan oleh orang tua dengan tipe ini akan berkembangan menjadi anak yang mandiri, penuh keyakinan, percaya, tidak cepat putus asa dan tidak takut salah dalam mengembangkan potensinya. ${ }^{67}$ Anak akan memiliki hubungan sosial yang baik, bersikap terbuka dan mudah menyesuaikan diri dengan lingkungan. ${ }^{6}$

${ }^{60}$ Much Solehudin, "Peran Guru PAI dalam Mengembangkan Kecerdasan Emosional (EQ) dan kecerdasan spiritual (SQ) Siswa SMK Komputama Majenang," Jurnal Tawadhu 2, no. 1 (2018): 303-25.

${ }^{61}$ Annisa Anita Dewi, Guru mata tombak pendidikan (CV Jejak (Jejak Publisher), 2018).

${ }^{62}$ Shilphy A. Octavia, Motivasi belajar dalam perkembangan remaja (Deepublish, 2020).

${ }^{63}$ Evi Aeni Rufaedah, “Teori Belajar Behavioristik Menurut Perspektif Islam,” Risâlah, Jurnal Pendidikan Dan Studi Islam 4, no. 1, March (2018): 13-30.

${ }^{64}$ Afi Parnawi, Psikologi belajar (Deepublish, 2019).

${ }^{65}$ M. Ngalim Purwanto, Psikologi Pendidikan (Bandung: Remaja Rosdakarya, 2017).

${ }^{66}$ Novita Angraeni dkk., "Pola Asuh Demokratis untuk Mengembangkan Perilaku Altruisme Anak di Era Global," Journal of Innovative Counseling: Theory, Practice, and Research 2, no. 02 (2018): 51-56.

67 Al.Tridonanto, Mengembangkan Pola Asub Demokratis (Elex Media Komputindo, 2014).

${ }^{68}$ Rabiatul Adawiah, "Pola asuh orang tua dan implikasinya terhadap pendidikan anak: Studi pada Masyarakat Dayak di Kecamatan Halong Kabupaten Balangan," Jurnal Pendidikan Kewarganegaraan 7, no. 1 (2017): 33-48; Dewi Candrawati, "Persepsi terhadap pola asuh 
Kedua, tipe mengekang. Orang tua yang memiliki tipe pelayanan mengekang akan cenderung bersifat otoriter dan suka melarang anaknya. ${ }^{69}$ Menuntut anaknya untuk patuh terhadap perintah orang tua, suka mengurung jika anaknya melakukan kesalahan dan cenderung ringan tangan. ${ }^{70}$ Tipe pelayanan orang tua seperti ini akan menimbulkan dampak yang tidak baik bagi anak. ${ }^{71}$ Anak merasa tidak dihargai, timbul sikap jengkel, kecewa bahkan takut terhadap orang tua, akibatnya adalah anak mengalami kehausan emosi, kurang kreatif, suka menggangu orang lain, dihantui perasaan bersalah ketika berbuat sesuatu bahkan dapat mendorong anak untuk berbuat nakal. ${ }^{72}$ Jika ini terus terjadi, maka akan mempengaruhi individu dalam menguasai tugas-tugas pada masa selanjutnya.

Ketiga, tipe pelayanan orang tua yang mengabaikan. Orang tua yang memiliki tipe pelayanan ini cenderung membiarkan anaknya, tidak memperdulikan anaknya dan selalu memberikan kebebasan yang berlebihan kepada anaknya. ${ }^{73}$ Tipe pelayanan orang tua seperti ini, di satu sisi kemandirian anak dapat berkembang secara maksimal. Namun di sisi lain anak akan selalu mengikuti keinginannya dan sangat terikat dengan teman sekelompoknya. ${ }^{74}$ Akibatnya adalah sikap, kebiasaan, perilaku, cara bicara bahkan cara berpakaian pun sangat dipengaruhi teman sekelompoknya. ${ }^{75}$

Keempat, tipe pelayanan orang tua yang bermusuhan. Orang tua yang memiliki tipe pelayanan ini selalu memusuhi bahkan ada yang sampai melakukan

demokratis dan konsep diri terhadap penyesuaian diri pada mahasiswa," Psikostudia: Jurnal Psikologi 8, no. 2 (2019): 99-107.

69 Katmini Katmini dan Abd Syakur, "Pola Asuh Orang Tua Otoriter dengan Kemampuan Activities Of Daily Living (ADL) pada Anak Retardasi Mental Usia 6-12 Tahun di SLB Yayasan Putra Asih Kediri Tahun 2018," Briliant: Jurnal Riset dan Konseptual 5, no. 1 (2020): 163-71.

70 Qurrotu Ayun, "Pola asuh orang tua dan metode pengasuhan dalam membentuk kepribadian anak," ThufuLA: Jurnal Inovasi Pendidikan Guru Raudhatul Athfal 5, no. 1 (2017): 102_ 22.

${ }^{71}$ Noor Baiti, "Pengaruh Pendidikan, Pekerjaan dan Pola Asuh Orang Tua terhadap Kemandirian Anak," JEA (Jurnal Edukasi AUD) 6, no. 1 (2020): 44-57.

${ }^{72}$ Katmini dan Syakur, "Pola Asuh Orang Tua Otoriter dengan Kemampuan Activities Of Daily Living (ADL) pada Anak Retardasi Mental Usia 6-12 Tahun di SLB Yayasan Putra Asih Kediri Tahun 2018"; Adristinindya Citra Nur Utami dan Santoso Tri Raharjo, "Pola Asuh Orang Tua Dan Kenakalan Remaja," Focus: Jurnal Pekerjaan Sosial 2, no. 1 (2019): 150-67.

${ }^{73}$ Farieska Fellasari dan Yuliana Intan Lestari, "Hubungan Antara Pola Asuh Orangtua dengan Kematangan Emosi Remaja," Jurnal Psikologi 12, no. 2 (2017): 84-90; Bagas Kurnianto dan Ravita Deasy Rahmawati, "Hubungan pola asuh Orang Tua terhadap motivasi belajar siswa pada pembelajaran Daring Masa Pandemi," dalam Seminar Pendidikan Nasional (SENDIKA), vol. 2, 2020 .

${ }^{74}$ Aslan Aslan, "Peran Pola Asuh Orangtua di Era Digital," Jurnal Studia Insania 7, no. 1 (2019): 20-34.

75 Wiwin Rinanti, "Pengaruh Tipe Pola Asuh Orangtua Terhadap Harga Diri pada Mahasiswa Psikologi Tahun Akademik 2016 di Universitas Muhammadiyah Purwokerto" (P.hD Thesis, Universitas Muhammadiyah Purwokerto, 2018). 
kekejaman terhadap anaknya. ${ }^{76}$ Orang tua tipe ini benar-benar tidak menyukai anaknya dan tidak memenuhi anaknya secara pantas walaupun orang tua itu mampu. ${ }^{77}$ Anak yang dibesarkan orang tua yang memiliki tipe ini akan bersikap agresif, suka membangkang dan suka merusak. ${ }^{78}$ Orang tua yang selalu bersikap bermusuhan terhadap anak, maka anak akan berkembang menjadi anak yang pasif, tidak berdaya, selalu ketergantungan dan tidak memiliki motivasi serta gairah untuk belajar. ${ }^{7}$

\section{Penutup}

Secara keseluruhan rata-rata tingkat pencapaian tingkat perkembangan berada pada tingkat individualitas. Skor paling tinggi penguasaan tugas perkembangan yang dicapai oleh mahasiswa pada aspek kesadaran tanggung jawab, sedangkan yang paling rendah tingkat ketercapaiannya pada aspek landasan prilaku etis. Tingkat ketercapaian pada setiap aspek perkembangan masing-masing program studi semuanya berada pada tingkatan yang sama, yaitu berada pada tingkat individualitas. Ada beberapa aspek tugas perkembangan pada mahasiswa program studi PAI dan BKPI yang sudah mencapai tingkat otonomi, yaitu aspek kesadaran tangung jawab. Mahasiswa program studi TBI pada aspek landasan hidup religious dan penerimaan diri serta pengembangannya juga sudah mencapai tingkat otonomi. Tingkat pencapaian tugas perkembangan mahasiswa program studi PGMI dan PBA semuanya berada pada tingkat individualitas.

\section{Daftar Pustaka}

Adawiah, Rabiatul. "Pola asuh orang tua dan implikasinya terhadap pendidikan anak: Studi pada Masyarakat Dayak di Kecamatan Halong Kabupaten Balangan." Jurnal Pendidikan Kewarganegaraan 7, no. 1 (2017): 33-48.

Agustang, Andi. "Kesejahteraan Psikologis (studi Pada Dewasa Madya yang Belum Menikah di Kota Makassar)," 2021.

Agustina, Novita, Okvantia Nurmaisara, dan Tyas Martika Anggriana. "Upaya Meningkatkan Kematangan Pemilihan Karir melalui Bimbingan Kelompok dengan Teknik Problem Solving” 1 (2017): 6.

${ }^{76}$ Imam Sibawaih dan Anita Tri Rahayu, "Analisis Pola Asuh Orang Tua terhadap Gaya Belajar Siswa di Sekolah Menengah Atas Kharismawita Jakarta Selatan," Research and Development Journal of Education 3, no. 2 (24 April 2017), https://doi.org/10.30998/rdje.v3i2.2014.

${ }^{77}$ Stephanus Turibius Rahmat, "Pola Asuh Yang Efektif Untuk Mendidik Anak di Era Digital" 10 (2018): 19.

${ }^{78}$ Kustiah Sunarty, "Hubungan Pola Asuh Orangtua Dan Kemandirian Anak," Journal of Educational Science and Technology (EST) 2, no. 3 (29 Desember 2016): 152-60, https://doi.org/10.26858/est.v2i3.3214.

${ }^{79}$ Kurnianto dan Rahmawati, "Hubungan pola asuh Orang Tua terhadap motivasi belajar siswa pada pembelajaran Daring Masa Pandemi." 
Agustriyana, Nur Astuti, dan Insan Suwanto. "Fully human being pada remaja sebagai pencapaian perkembangan identitas." Jurnal Bimbingan Konseling Indonesia 2, no. 1 (2017): 9-11.

Al.Tridonanto. Mengembangkan Pola Asub Demokratis. Elex Media Komputindo, 2014.

Angraeni, Novita, Sely Sisca Andriani, Shinta Muliawati, dan Charis Faozi. "Pola Asuh Demokratis untuk Mengembangkan Perilaku Altruisme Anak di Era Global." Journal of Innovative Counseling: Theory, Practice, and Research 2, no. 02 (2018): 51-56.

Ansoriy, Zakaria. "Kebiasaan Membaca Al Qur'an dan Implikasinya Terhadap Kecerdasan Intelektualitas Mahasiswa." OSF Preprints, 2021.

Anwar, R. Anggoro Rahardjo Harry. "Peran Perguruan Tinggi dalam Pengembangan Kepedulian Sosial Mahasiswa." SOSIOHUMANITAS 20, no. 1 (2018).

Aslan, Aslan. "Peran Pola Asuh Orangtua di Era Digital." Jurnal Studia Insania 7, no. 1 (2019): 20-34.

Ayun, Qurrotu. "Pola asuh orang tua dan metode pengasuhan dalam membentuk kepribadian anak." ThufuLA: Jurnal Inovasi Pendidikan Guru Raudhatul Atbfal 5, no. 1 (2017): 102-22.

Azizah, Faricha, Fitri Br Ginting, dan Robbi Suraida Utami. "Evaluasi Pelaksanaan Program Layanan Bimbingan dan Konseling di Sekolah." Dalam Prosiding Seminar Bimbingan dan Konseling, 1:177-88, 2017.

Azizah, Nadia Nur, dan Aan Asef Richval. "Pertumbuhan dan Perkembangan dalam Psikologi Perkembangan." http://eprints.umsida.ac.id/1273/, 2018, $1-13$.

Baiti, Noor. "Pengaruh Pendidikan, Pekerjaan dan Pola Asuh Orang Tua terhadap Kemandirian Anak." JEA Jurnal Edukasi AUD) 6, no. 1 (2020): 44-57.

Candrawati, Dewi. "Persepsi terhadap pola asuh demokratis dan konsep diri terhadap penyesuaian diri pada mahasiswa." Psikostudia: Jurnal Psikologi 8, no. 2 (2019): 99-107.

Creswell, John W. Research Designi: Pendekatan Metode Kualitatif, Kuantitatif dan Campuran. Yogyakarta: Pustaka Pelajar, 2017.

Dewi, Annisa Anita. Guru mata tombak pendidikan. CV Jejak (Jejak Publisher), 2018.

Elida Prayitno. Psikologi Perkembangan Remaja. Padang: UNP, 2002. 
Erpiana, Anna, dan Endang Fourianalistyawati. "Peran trait mindfulness terhadap psychological well-being pada dewasa awal." Psympatbic: Jurnal Ilmiah Psikologi 5, no. 1 (2018): 67-82.

Fellasari, Farieska, dan Yuliana Intan Lestari. "Hubungan antara pola asuh orangtua dengan kematangan emosi remaja." Jurnal Psikologi 12, no. 2 (2017): 84-90.

Guswani, Aprius Maduwita, dan Fajar Kawuryan. "Perilaku agresi pada mahasiswa ditinjau dari kematangan emosi." Jurnal Psikologi UMK: PITUTUR 1, no. 2 (2011): 86-92.

Helson, Ravenna M., dan Valory Mitchell. "8. Loevinger's Theory of Ego Development." Dalam Women on the River of Life, 113-26. University of California Press, 2020.

Herawati, Icha, dan Ahmad Hidayat. "Quarterlife Crisis Pada Masa Dewasa Awal di Pekanbaru." Journal An-Nafs: Kajian Penelitian Psikologi 5, no. 2 (2020): 145-56.

Herawati, Nenden Ineu. "Mengembangkan Program Layanan Bimbingan dan Konseling untuk Meningkatkan Tugas Perkembangan Mahasiswa Upi Kampus Cibiru." Cakrawala Dini: Jurnal Pendidikan Anak Usia Dini 6, no. 1 (2018).

Hildayani, Rini, Mayke Sugianto, Rosdiana Tarigan, dan Eko Handayani. "Psikologi perkembangan anak," 2014.

Hulukati, Wenny, dan Moh Rizki Djibran. "Analisis tugas perkembangan mahasiswa fakultas ilmu pendidikan universitas negeri gorontalo." Bikotetik (Bimbingan Dan Konseling: Teori Dan Praktik) 2, no. 1 (2018): 73 80.

Hurlock, Elizabeth B. Psikologi Perkembangan, Suatu Pendekatan Sepanjang Rentang Kehidupan. Jakarta: Erlangga, 1991.

Indati, Aisah. "Konsep Kearifan pada Dewasa Awal, Tengah, dan Akhir." psychologyforum.umm.ac.id Prosiding Temilnas XI IPPI (20 September 2019).

Jamaluddin, Jamaluddin, Acep Komarudin, dan Asep Andi Rahman. "Bimbingan orang tua dalam mengembangkan kepribadian anak." Atthulab: Islamic Religion Teacbing and Learning Journal 4, no. 2 (2019): 17084.

Jannah, Miftahul. "Remaja dan tugas-tugas perkembangannya dalam Islam." Psikoislamedia: Jurnal Psikologi 1, no. 1 (2017).

Jannah, Miftahul, Siti Rozaina Kamsani, dan Nurhazlina Mohd Ariffin. "Perkembangan Usia Dewasa: Tugas dan Hambatan pada Korban 
Konflik Pasca Damai." Bunayya: Jurnal Pendidikan Anak 8, no. 2 (2021): 114-43.

Kartadinata, Sunaryo, dan dkk. Petunjuk Teknis Penggunaan Inventori Tugas Perkembangan Mabasiswa (ITP-PT). Bandung: UPI, 2003.

Katmini, Katmini, dan Abd Syakur. "Pola Asuh Orang Tua Otoriter dengan Kemampuan Activities Of Daily Living (ADL) pada Anak Retardasi Mental Usia 6-12 Tahun di SLB Yayasan Putra Asih Kediri Tahun 2018." Briliant: Jurnal Riset dan Konseptual 5, no. 1 (2020): 163-71.

Khairun, Deasy Yunika, dan Meila Dwi Nurmala. "Program Bimbingan dan Konseling Mahasiswa FKIP Untirta Berbantuan Software Analisis Tugas Perkembangan.” Jurnal Penelitian Bimbingan dan Konseling 5, no. 1 (2020).

Kurnianto, Bagas, dan Ravita Deasy Rahmawati. "Hubungan pola asuh Orang Tua terhadap motivasi belajar siswa pada pembelajaran Daring Masa Pandemi." Dalam Seminar Pendidikan Nasional (SENDIKA), Vol. 2, 2020.

Lubis, Syahron. Metodologi Penelitian Kuantitatif. Padang: UNP P, 2003.

Mahmudi, Arifudin, Joko Sulianto, dan Ikha Listyarini. "Hubungan Perhatian Orang Tua Terhadap Hasil Belajar Kognitif Siswa." Jurnal Pedagogi dan Pembelajaran 3, no. 1 (2020): 122-29.

Marwoko, Gatot. "Psikologi Perkembangan Masa Remaja." Tasyri: Jurnal Tarbiyah-Syariab-Islamiyah 26, no. 1 (2019): 60-75.

Maulidya, Faricha, dan Mirta Adelina. "Periodesasi Perkembangan Dewasa." Periodesasi Perkembangan Dewasa, 2018, 1-10.

Nazir. Metode Penelitian. Bogor: Ghalia Indonesia, 2015.

Nisa, Nurul, dan Triana Lestari. "Pengaruh Sikap Orang Tua yang Overprotektive terhadap Perkembangan Kemandirian Anak." Jurnal Elementary : Kajian Teori dan Hasil Penelitian Pendidikan Sekolab Dasar 4, no. 2 (29 Juni 2021): 112-15. https://doi.org/10.31764/elementary.v4i2.4747.

Novita, Lina, dan Anisa Agustina. "Bimbingan Orang Tua Dengan Disiplin Siswa." Pedagonal: Jurnal Ilmiah Pendidikan 2, no. 1 (2018): 1-14.

Octavia, Shilphy A. Motivasi belajar dalam perkembangan remaja. Deepublish, 2020.

Panggayuh, Vertika. "Pengaruh kemampuan metakognitif terhadap prestasi akademik mahasiswa pada mata kuliah pemrograman dasar." JIPI (Jurnal Ilmiab Penelitian Dan Pembelajaran Informatika) 2, no. 1 (2017).

Parnawi, Afi. Psikologi belajar. Deepublish, 2019. 
Pello, Sindhy Mariam Magdalena, dan Christiana Hari Soetjiningsih. "Kebahagiaan pada Wanita Dewasa Madya yang Melajang." Psikologi Konseling 16, no. 1 (2020).

Prayitno, Elida. Perkembangan Peserta Didik. Jakarta: Dirjen Dikti, 1999.

Priyambodo, Aji Bagus, dan Hendi Setyawan. "Problematika Sosial Mahasiswa di Universitas Negeri Malang Ditinjau Dari Perspektif Perkembangan Psikososial." Dalam Prosiding Seminar Nasional \& Call Paper Psikologi Sosial, 2019.

Purwanto, M. Ngalim. Psikologi Pendidikan. Bandung: Remaja Rosdakarya, 2017.

Putera, Jihad Pamungkas. "Psikologi Perkembangan,” 2011.

Putri, Alifia Fernanda. "Pentingnya orang dewasa awal menyelesaikan tugas perkembangannya." SCHOULID: Indonesian Journal of School Counseling 3, no. 2 (2019): 35-40.

Rahmat, Pupu Saeful. Perkembangan peserta didik. Bumi Aksara, 2021.

Rahmat, Stephanus Turibius. "Pola Asuh Yang Efektif Untuk Mendidik Anak di Era Digital” 10 (2018): 19.

Ramdhani, Rina Nurhudi, Amin Budiamin, dan Nandang Budiman. "Adaptabilitas Karir Dewasa Awal." Jurnal Penelitian Pendidikan 18, no. 3 (2019): 361-70.

RiantiI, Wiwin. "Pengaruh Tipe Pola Asuh Orangtua Terhadap Harga Diri pada Mahasiswa Psikologi Tahun Akademik 2016 di Universitas Muhammadiyah Purwokerto." PhD Thesis, Universitas Mummadiyah Purwokerto, 2018.

Ridwan. Dasar-dasar Statistik. Bandung: Alfabeta, 2017.

Rufaedah, Evi Aeni. "Teori Belajar Behavioristik Menurut Perspektif Islam.” Risâlah, Jumal Pendidikan Dan Studi Islam 4, no. 1, March (2018): 13-30.

Ruli, Efrianus. "Tugas dan Peran Orang Tua dalam Mendidk Anak." Jumal Edukasi Nonformal 1, no. 2 (2020): 143-46.

Safitri, Safitri. "Gambaran Tugas Perkembangan Mahasiswa Psikologi Universitas Esa Unggul.” Jurnal Psikologi: Media Imiah Psikologi 16, no. 1 (2018).

Santrock, John. W. Life Span Development: Perkembangan Masa Hidup Jilid II. Jakarta: Erlangga, 2015.

Saputro, Khamim Zarkasih. "Memahami ciri dan tugas perkembangan masa remaja." Aplikasia: Jurnal Aplikasi Ilmu-ilmu Agama 17, no. 1 (2018): 2532. 
Saputro, Yusup Adi, dan Rini Sugiarti. "Pengaruh Dukungan Sosial Teman Sebaya dan Konsep Diri terhadap Penyesuaian Diri pada Siswa SMA Kelas X." Philanthropy: Journal of Psychology 5, no. 1 (2021): 59-72.

Sari, Kurnia. "Korelasi Motivasi Mahasiswa dalam Mengikuti Perkuliahan Terhadap Perencanaan Karier." Jurnal Fokus Konseling 4, no. 1 (2018): $136-42$.

Sibawaih, Imam, dan Anita Tri Rahayu. "Analisis Pola Asuh Orang Tua terhadap Gaya Belajar Siswa di Sekolah Menengah Atas Kharismawita Jakarta Selatan." Research and Development Journal of Education 3, no. 2 (24 April 2017). https://doi.org/10.30998/rdje.v3i2.2014.

Solehudin, Much. "Peran Guru PAI dalam Mengembangkan Kecerdasan Emosional (EQ) dan kecerdasan spiritual (SQ) Siswa SMK Komputama Majenang." Jurnal Tawadhu 2, no. 1 (2018): 303-25.

Subekti, Fitrianto Eko, dan Akhmad Jazuli. "Peningkatan Kemampuan Pemecahan Masalah dan Kemandirian Belajar Mahasiswa Melalui Pembelajaran Berbasis Masalah." JNPM Jurnal Nasional Pendidikan Matematika) 4, no. 1 (2020): 13-27.

Sugiono. Metode penelitian pendidikan: Pendekatan kuantitatif, kualitatif dan $\mathrm{R} \& \mathrm{D}$, Bandung: Alfabeta, 2019.

Sumanty, Dessy, Deden Sudirman, dan Diah Puspasari. "Hubungan religiusitas dengan citra tubuh pada wanita dewasa awal." Jurnal Psikologi Islam dan Budaya 1, no. 1 (2018): 9-28.

Sunarty, Kustiah. "Hubungan Pola Asuh Orangtua Dan Kemandirian Anak." Journal of Educational Science and Technology (EST) 2, no. 3 (29 Desember 2016): 152-60. https://doi.org/10.26858/est.v2i3.3214.

Tukinem, Tukinem. "Mendidik anak dalam perspektif Islam (Kajian syarah Riyadhu-sh-Shalihin)." Journal of Islamic Education and Innovation 1, no. 2 (2020): 39-49.

Utami, Adristinindya Citra Nur, dan Santoso Tri Raharjo. "Pola Asuh Orang Tua Dan Kenakalan Remaja." Focus: Jurnal Pekerjaan Sosial 2, no. 1 (2019): 150-67.

Utami, Vania, dan Lukmanul Hakim. "Hubungan Harga Diri dengan Kecemasan Memilih Pasangan Hidup pada Perempuan Dewasa Awal." Jurnal Psimawa 2, no. 1 (2019): 15-20.

Wahyudhi, Qudsi Iftikar, Tulus Winarsunu, dan Sofa Amalia. "Kematangan sosial dan problem focused coping pada laki-laki usia dewasa awal." Jurnal Ilmiah Psikologi Terapan 7, no. 1 (2019): 52-64.

Wibowo, Agus, Nurul Atieka, dan Hadi Pranoto. "Peningkatan Kapasistas Konselor di Perguruan Tinggidalam Kompleksitas Problematika 
266 | Islamic Counseling: Jurnal Bimbingan dan Konseling Islam, Vol. 5, No. 2, 2021

Mahasiswa." Dalam Prosiding Seminar Nasional Bimbingan dan Konseling di Perguruan Tinggi Bandung, Vol. 6, 2018. 